Portland State University

PDXScholar

\title{
Implementing the Green Dot Bystander Intervention Program to Promote Respectful Workplaces in the Construction Trades in Oregon
}

\author{
Maura Kelly \\ Portland State University \\ Lindsey Wilkinson \\ Portland State University
}

Follow this and additional works at: https://pdxscholar.library.pdx.edu/trec_reports

Part of the Transportation Commons, and the Urban Studies Commons Let us know how access to this document benefits you.

\section{Recommended Citation}

Kelly, Maura and Lindsey Wilkinson. Implementing the Green Dot Bystander Intervention Program to Promote Respectful Workplaces in the Construction Trades in Oregon. NITC-RR1078. Portland, OR: Transportation Research and Education Center (TREC), 2018. http://doi.org/10.15760/trec.206

This Report is brought to you for free and open access. It has been accepted for inclusion in TREC Final Reports by an authorized administrator of PDXScholar. Please contact us if we can make this document more accessible: pdxscholar@pdx.edu. 


\section{FINAL REPORT}

Implementing the Green Dot Bystander Intervention Program to Promote Respectful Workplaces in the Construction Trades in Oregon

NITC-RR-1078 August 2018

NITC is a U.S. Department of Transportation national university transportation center.

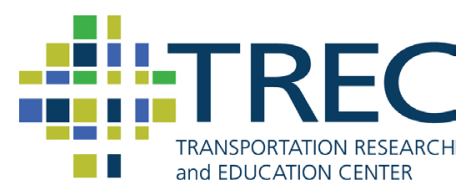





\title{
IMPLEMENTING THE GREEN DOT BYSTANDER INTERVENTION PROGRAM \\ TO PROMOTE RESPECTFUL WORKPLACES IN THE CONSTRUCTION TRADES IN OREGON
}

\author{
Interim Report \\ NITC-RR 1078 \\ by \\ Maura Kelly and Lindsey Wilkinson \\ Portland State University
}

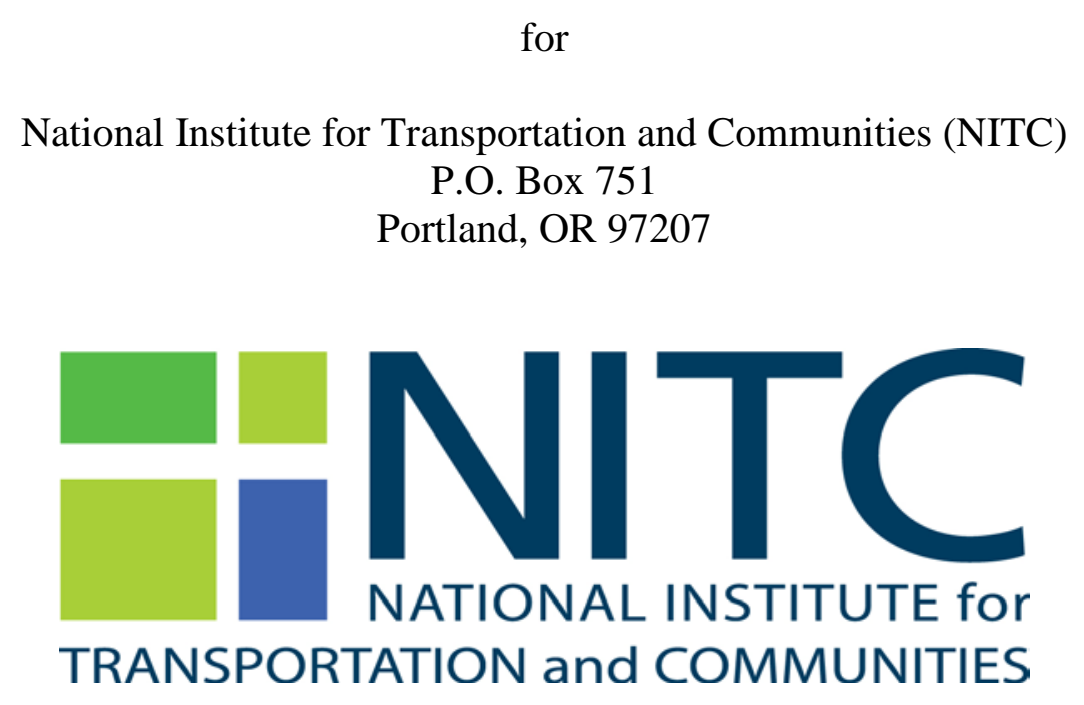

August 2018 



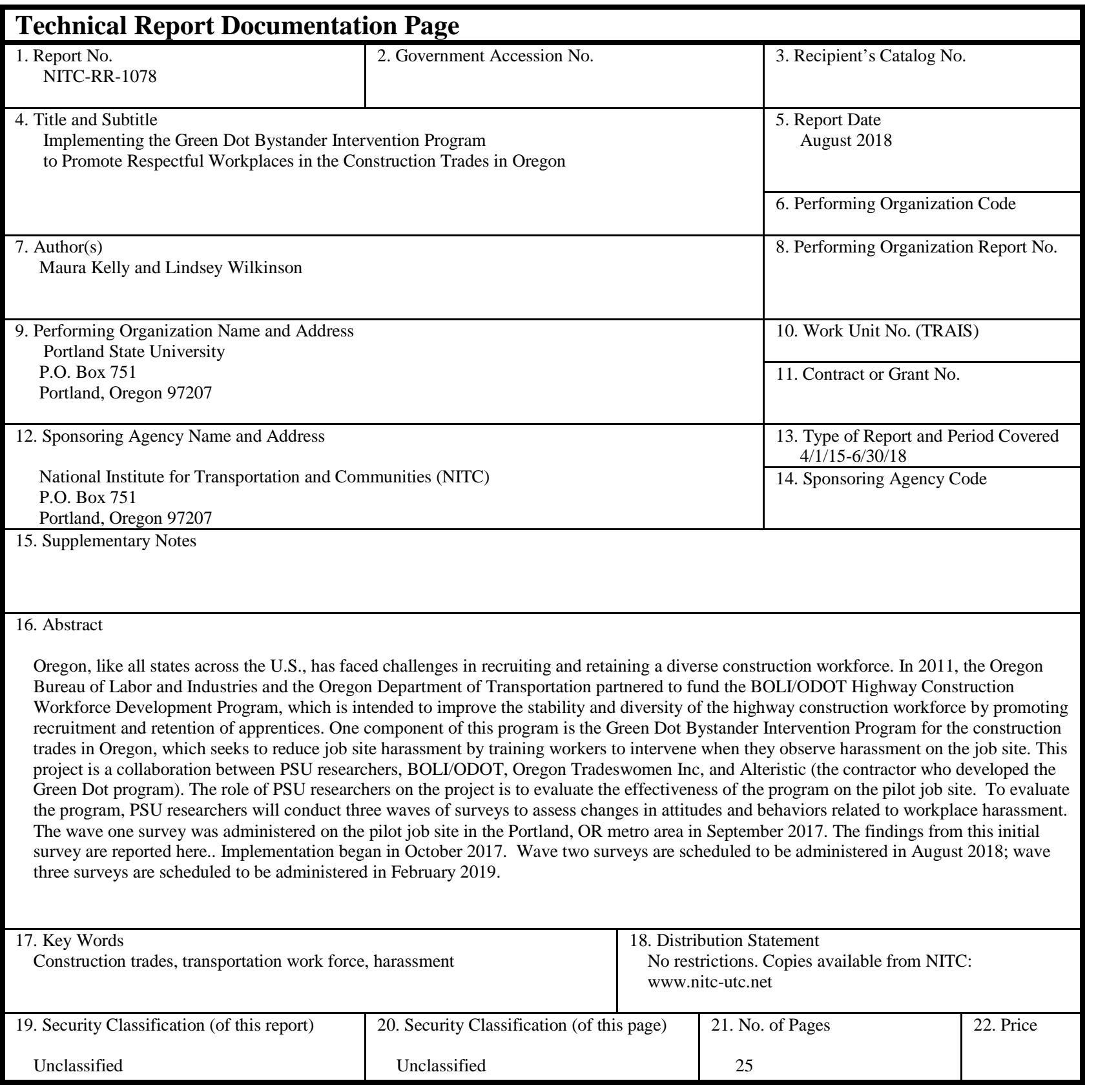




\section{ACKNOWLEDGEMENTS}

Maura Kelly and Lindsey Wilkinson would like to acknowledge support from the Oregon Bureau of Labor and Industries (BOLI) and the Oregon Department of Transportation (ODOT) as well as the National Institute for Transportation and Communities (NITC) under grant number (NITC-RR-1078).

\section{DISCLAIMER}

The contents of this report reflect the views of the authors, who are solely responsible for the facts and the accuracy of the material and information presented herein. This document is disseminated under the sponsorship of the U.S. Department of Transportation University Transportation Centers Program, Oregon Bureau of Labor and Industries, and the Oregon Department of Transportation in the interest of information exchange. The U.S. Government, Oregon Bureau of Labor and Industries, and the Oregon Department of Transportation assume no liability for the contents or use thereof. The contents do not necessarily reflect the official views of the U.S. Government, Oregon Bureau of Labor and Industries, and the Oregon Department of Transportation. This report does not constitute a standard, specification, or regulation.

\section{RECOMMENDED CITATION}

Kelly, Maura and Lindsey Wilkinson. Implementing the Green Dot Bystander Intervention Program to Promote Respectful Workplaces in the Construction Trades in Oregon. NITC-RR1078. Portland, OR: Transportation Research and Education Center (TREC), 2018. 
TABLE OF CONTENTS

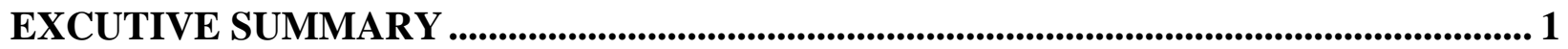

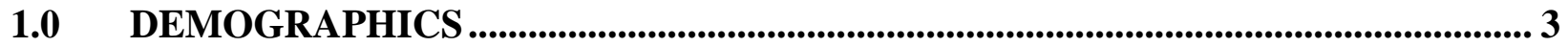

2.0 PERCEPTIONS OF REPORTING PRACTICES EXPECTED OF COMPANY ..... 3

3.0 ATTITUDES ABOUT JOBSITE HARASSMENT …............................................4

4.0 HARASSMENT EXPERIENCED AND OBSERVED IN THE LAST MONTH....... 4

5.0 ATTITUDES TOWARDS INTERVENING ............................................................... 6

6.0 EXPERIENCES INTERVENING IN THE LAST MONTH .................................... 7

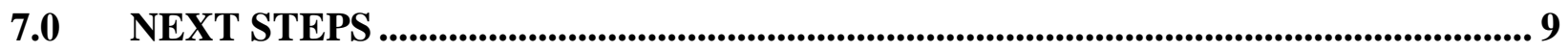

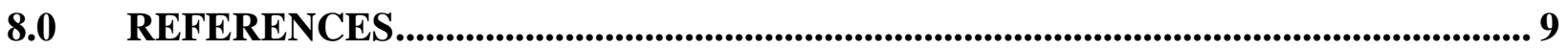

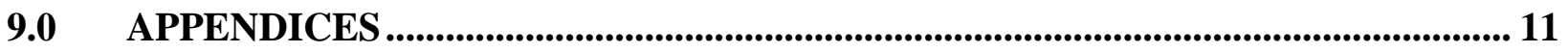

\section{APPENDICES}

APPENDIX A: SAMPLE CHARACTERISTICS

APPENDIX B: PERCENTAGE REPORTING SELECTED ITEMS BY DEMOGRAPHIC CATEGORIES

APPENDIX C: SURVEY QUESTIONNAIRE

\section{TABLE OF FIGURES}

Figure 2.1. Percentage of Workers Agreeing about Jobsite Reporting Practices.................... 3 Figure 3.1. Percentage of Workers Who Agree with Following Statements about Jobsite Harassment ............................................................................................................. 4

Figure 4.1. Percentage of Workers Experiencing Harassment on the Job Site in the Last Month, by Type of Harassment ....................................................................................... 5

Figure 4.2. Percentage of Workers Witnessing Harassment of Others on the Job Site in the

Last Month, by Type of Harassment ……………………........................................... 5

Figure 4.3. Percentage of Workers Called Names, Yelled At, or Cursed at on Job Site, by Demographic Characteristics ..................................................................................... 6

Figure 6.1. Percentage of Workers Reporting Bystander Intervention on the Job Site in the Last Month, by Type of Intervention. 


\section{EXCUTIVE SUMMARY}

\section{Background}

Oregon, like all states across the U.S., has faced challenges in recruiting and retaining a diverse construction workforce. In 2011, the Oregon Bureau of Labor and Industries and the Oregon Department of Transportation partnered to fund the BOLI/ODOT Highway Construction Workforce Development Program, which is intended to improve the stability and diversity of the highway construction workforce by promoting recruitment and retention of apprentices. One component of this program is the Green Dot Bystander Intervention Program for the construction trades in Oregon, which seeks to reduce job site harassment by training workers to intervene when they observe harassment on the job site. This project is a collaboration between PSU researchers, BOLI/ODOT, Oregon Tradeswomen Inc, and Alteristic (the contractor who developed the Green Dot program). The role of PSU researchers on the project is to evaluate the effectiveness of the program on the pilot job site.

\section{Method}

To evaluate the program, PSU researchers will conduct three waves of surveys to assess changes in attitudes and behaviors related to workplace harassment. The wave one survey was administered on the pilot job site in the Portland, OR metro area in September 2017. The findings from this initial survey are reported here. Implementation began in October 2017. Wave two surveys are scheduled to be administered in August 2018; wave three surveys are scheduled to be administered in February 2019.

\section{Overview of findings}

- Demographics: A total of 31 workers completed the wave one survey. Participants were $90 \%$ male and 68\% white (and non-Hispanic). 17\% were apprentices, 37\% were journey workers, and $40 \%$ were foremen/supervisors/superintendents/project managers (described as "supervisors" in this report).

- Perceptions of reporting practices expected of company: 97\% of respondents agreed that workers are expected to formally report harassment on the jobsite; $87 \%$ agreed supervisors address harassment on the jobsite when they see it; and 94\% agreed consequences exist for employees who engage in harassment on the jobsite.

- Attitudes towards jobsite harassment: $40 \%$ believed more should be done to address harassment on the job site; $48 \%$ agreed harassment negatively impacts safety on the jobsite, and $63 \%$ agreed harassment negatively impacts productivity on the job.

- Harassment experienced and observed in the last month: $48 \%$ of workers reported experiencing harassing behaviors on the job site in last month; 48\% reported witnessing harassing behaviors on the job site in last month. Women, people of color, journey workers and supervisors reported experiencing and seeing harassment more often than men, whites, 
and apprentices.

- Attitudes towards intervening: $100 \%$ of workers said they might intervene if they saw a coworker being harassed. A minority of workers noted they might not intervene because it might make a coworker angry, they might get harassed, or they might lose their job.

- Experiences intervening in the last month: 23\% of workers reported they actually intervened in the last month. Directly intervening by checking to see if a co-worker was okay or telling someone to stop harassing a co-worker were the most commonly reported forms of intervention.

\section{Next steps}

Wave two surveys are scheduled to be administered in August 2018; wave three surveys are scheduled to be administered in February 2019. The pilot study will be evaluated as successful if reported levels of harassment go down and reported bystander interventions go up. 


\subsection{DEMOGRAPHICS}

A total of 31 workers completed wave one surveys. Participants were: $90 \%$ male; $68 \%$ white (and non-Hispanic); and 17\% apprentices, 37\% journey worker, 40\% foremen/supervisors/ superintendents/project managers (described as "supervisors" in this report). The full demographics of the sample are show in Appendix A.

\subsection{PERCEPTIONS OF REPORTING PRACTICES EXPECTED OF COMPANY}

97\% of respondents agreed that workers are expected to formally report harassment on the jobsite, and $90 \%$ of respondents agreed workers are expected to informally report harassment on the jobsite. Only 19\% of respondents agreed that workers are expected to deal with harassment on the jobsite on their own. 87\% of respondents agreed supervisors address harassment when they see or hear it on the jobsite, and 94\% agreed there are consequences for employees who harass other workers on the jobsite (Figure 1).

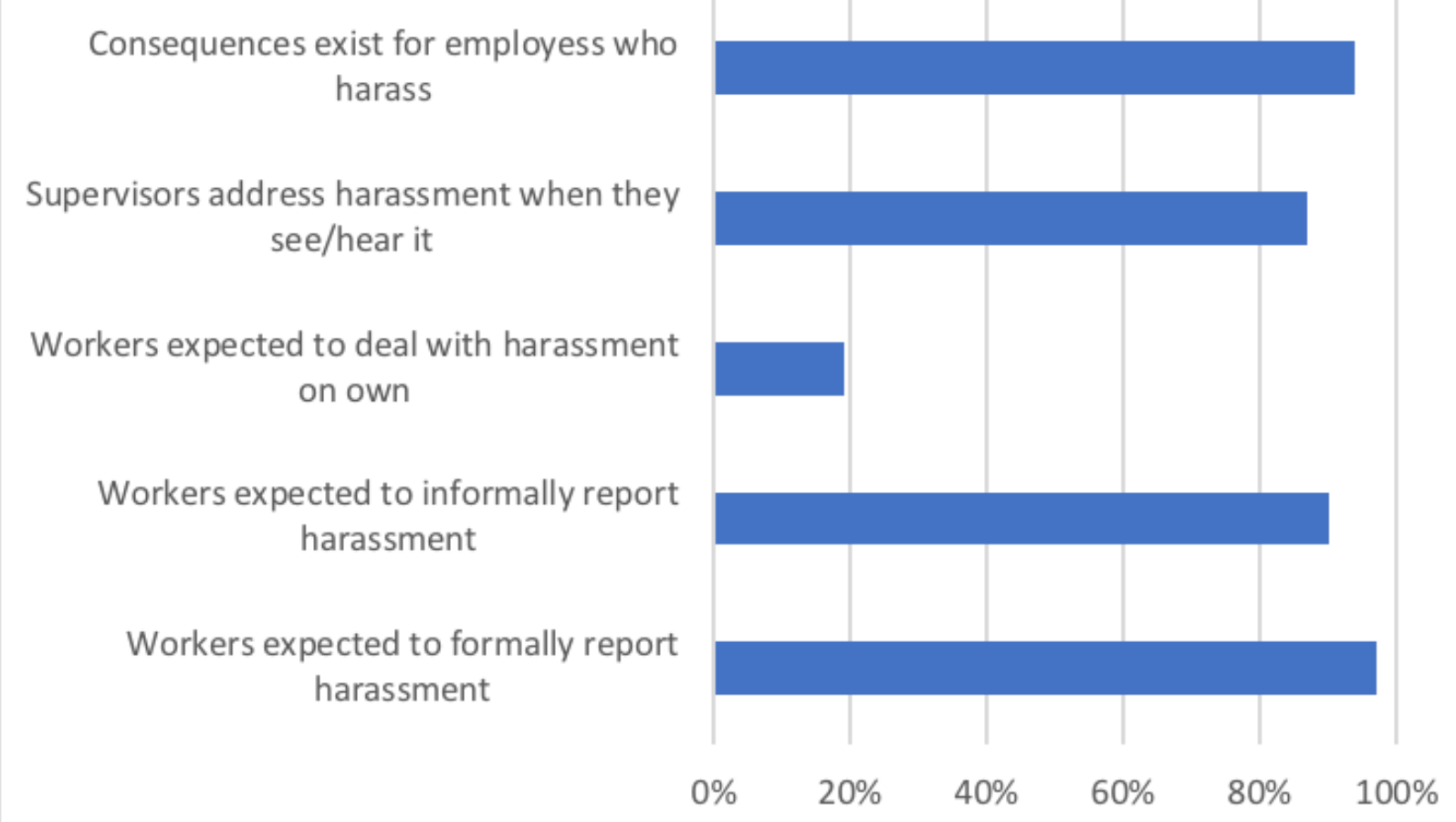

Figure 2.1. Percentage of Workers Agreeing about Jobsite Reporting Practices 


\subsection{ATTITUDES ABOUT JOBSITE HARASSMENT}

$13 \%$ of workers stated they believed harassment was a problem on the job site (although a much higher percentage reported experiencing or seeing harassing behaviors, see below). No workers reported considering leaving the trades because of harassment; however, $48 \%$ agreed harassment negatively impacts safety, and 63\% agreed harassment negatively impact productivity (Figure 2). In addition, $40 \%$ of workers believed more should be done to address harassment on the job site. Women, racial minorities, and supervisors were more likely than non-Latino white men to agree harassment is a problem on the jobsite (see Appendix B).

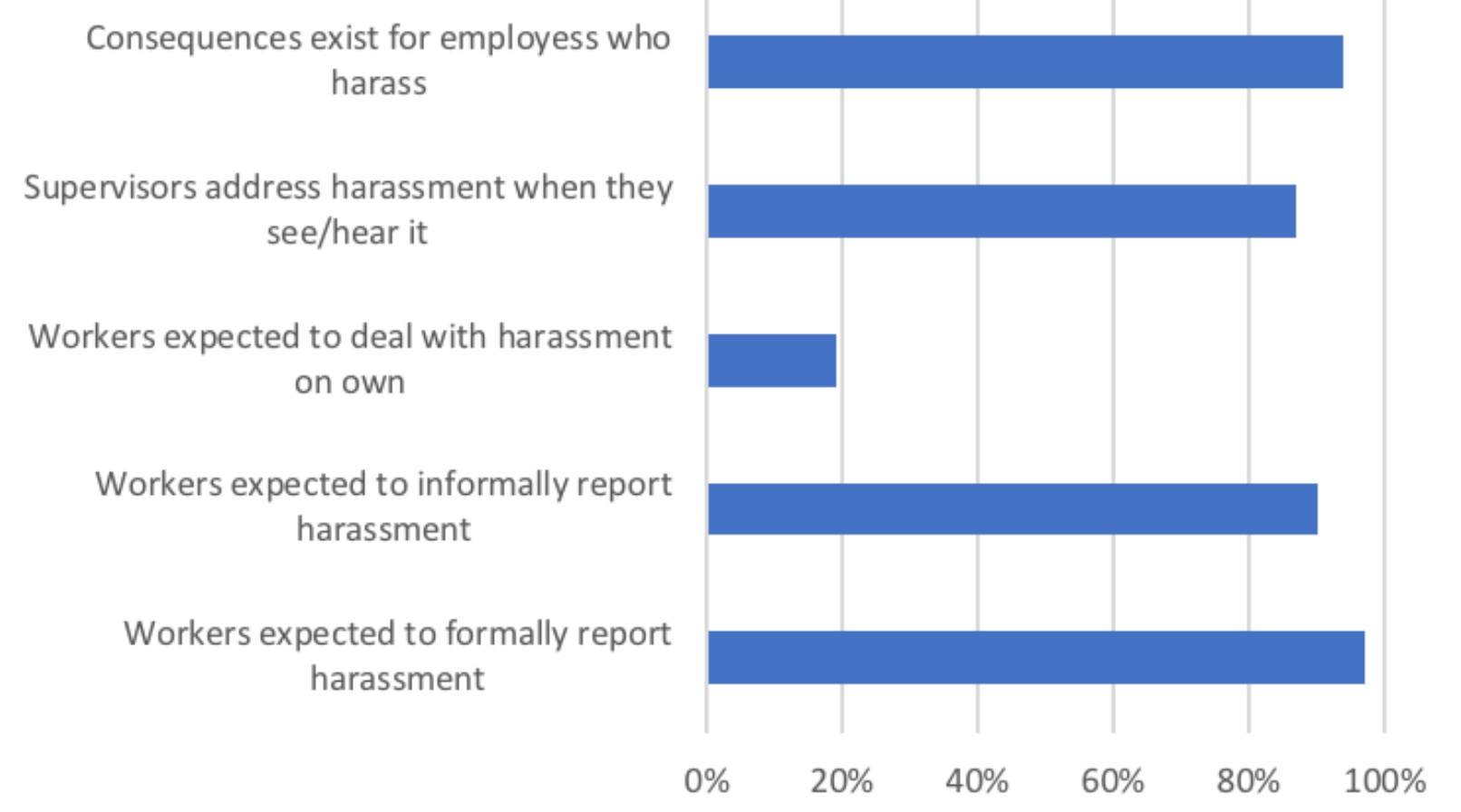

Figure 3.1. Percentage of Workers Who Agree with Following Statements about Jobsite Harassment

\subsection{HARASSMENT EXPERIENCED AND OBSERVED IN THE LAST MONTH}

$48 \%$ of workers reported being harassed on the job site in last month, and $48 \%$ reported 
witnessing harassment on the job site in last month. The patterns for experiencing (Figure 3) and observing different forms of harassment (Figure 4) were largely similar.

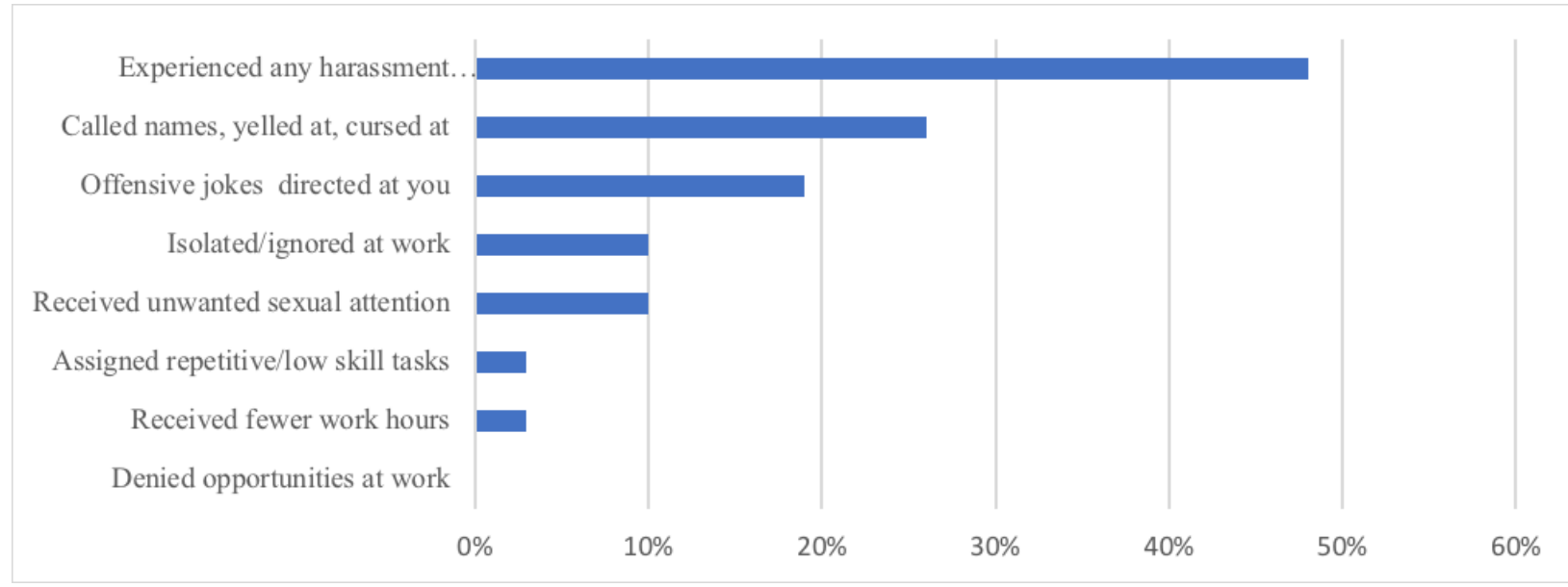

Figure 4.1. Percentage of Workers Experiencing Harassment on the Job Site in the Last Month, by Type of Harassment

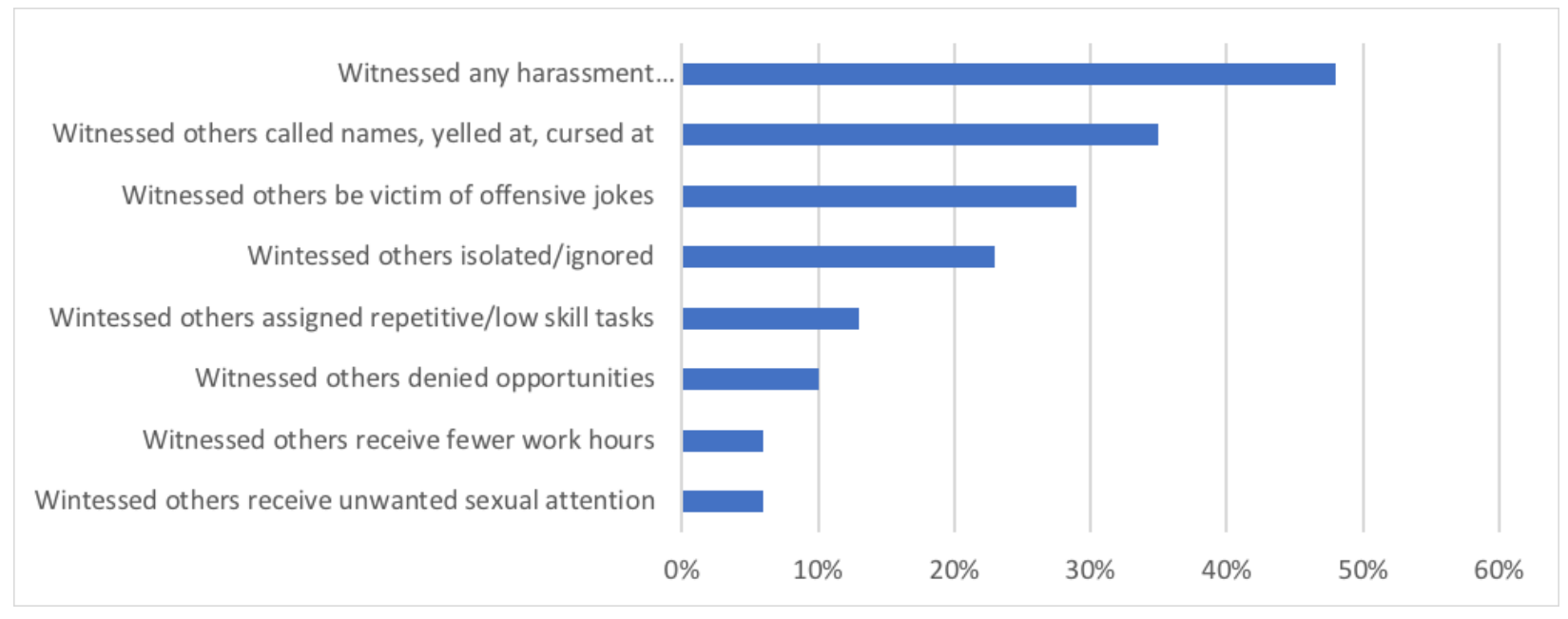

Figure 4.2. Percentage of Workers Witnessing Harassment of Others on the Job Site in the Last Month, by Type of Harassment

In open-ended questions, several participants noted examples of harassment they had observed:

Talking down to apprentices who are unfamiliar with the task being performed. Not having the experience does not mean they are incompetent.

Supervisor from a subcontractor stood above on the bank and yelled at employees.

Derogatory racial remarks. 
Aggressive attitudes instead of explaining a situation.

A few participants noted in the open-ended question that there was no harassment on the job site:

I believe supervisors address harassment before it happens. There isn't any on this jobsite. I have seen none, [this company] has a strong policy to deal with these actions.

This job seems to be very good. Everyone gets along from what I see.

Women, people of color, journey workers, and supervisors report experiencing and seeing harassment more often than men, whites, and apprentices (see Appendix B). Figure 5 shows the demographic differences for one common type of harassment: being called names, yelled at, or cursed at on the job site.

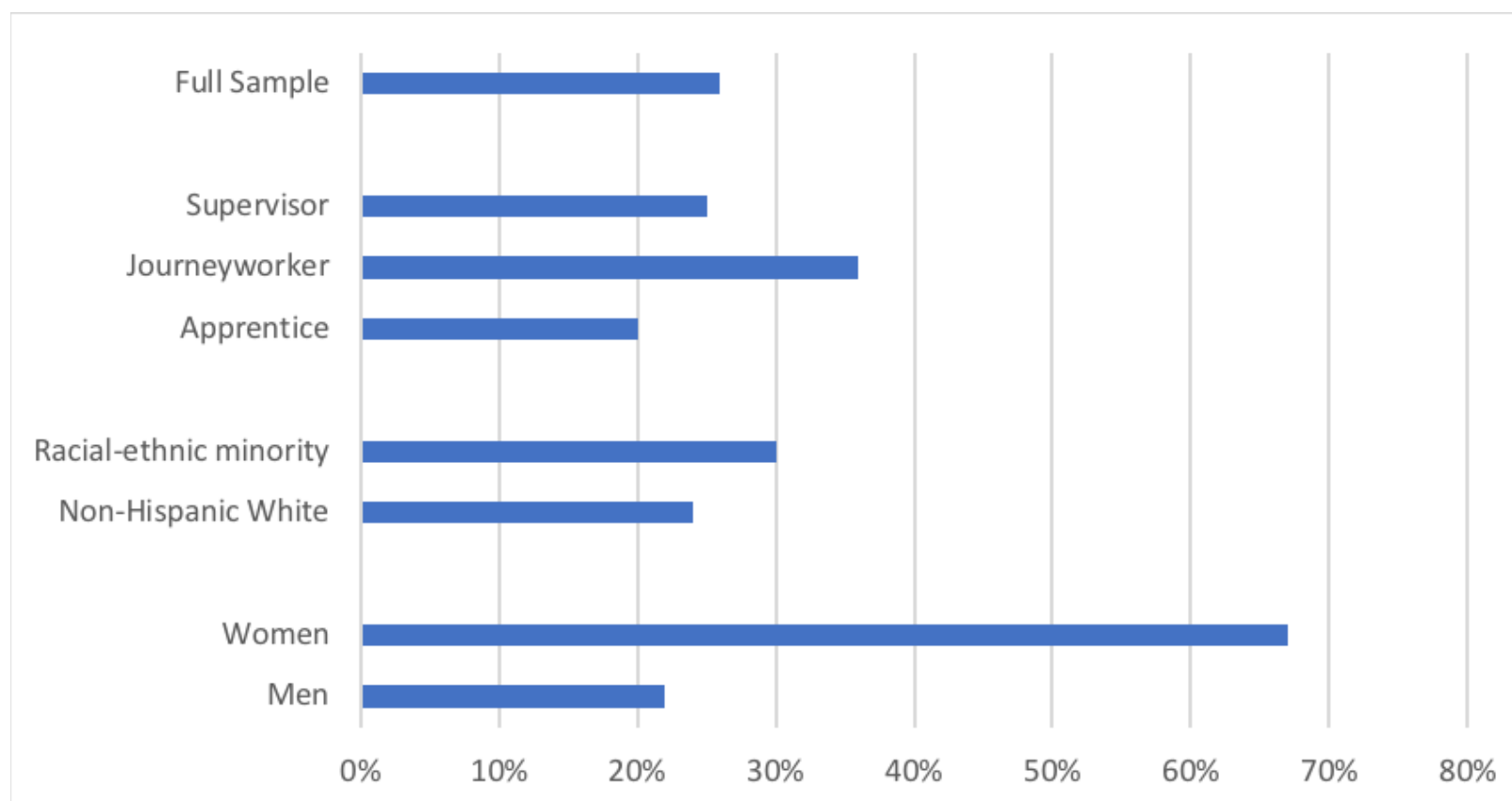

Figure 4.3. Percentage of Workers Called Names, Yelled At, or Cursed at on Job Site, by Demographic Characteristics

\subsection{ATTITUDES TOWARDS INTERVENING}

$100 \%$ of workers said they might intervene if they saw a coworker being harassed. A minority of workers noted they might not intervene because it might make a coworker angry, they might get harassed, or they might lose their job. Men were more likely than women, racial/ethnic minorities were more likely than whites, and journey workers and supervisors were more likely than apprentices to agree or strongly agree they might not intervene because it might make a coworker angry. A greater percentage of women, racial/ethnic minorities, journey workers, and supervisors believed they might not intervene because they might get harassed. A greater 
percentage of men, journey workers, and supervisors believed they might not intervene for fear of losing their job (see Appendix B).

\subsection{EXPERIENCES INTERVENING IN THE LAST MONTH}

$23 \%$ of the sample participated in a bystander intervention in last month. The average number of interventions was 2. As shown in Figure 6, directly intervening by checking to see if a co-worker was okay or telling someone to stop harassing a co-worker were the most commonly reported forms on intervention.

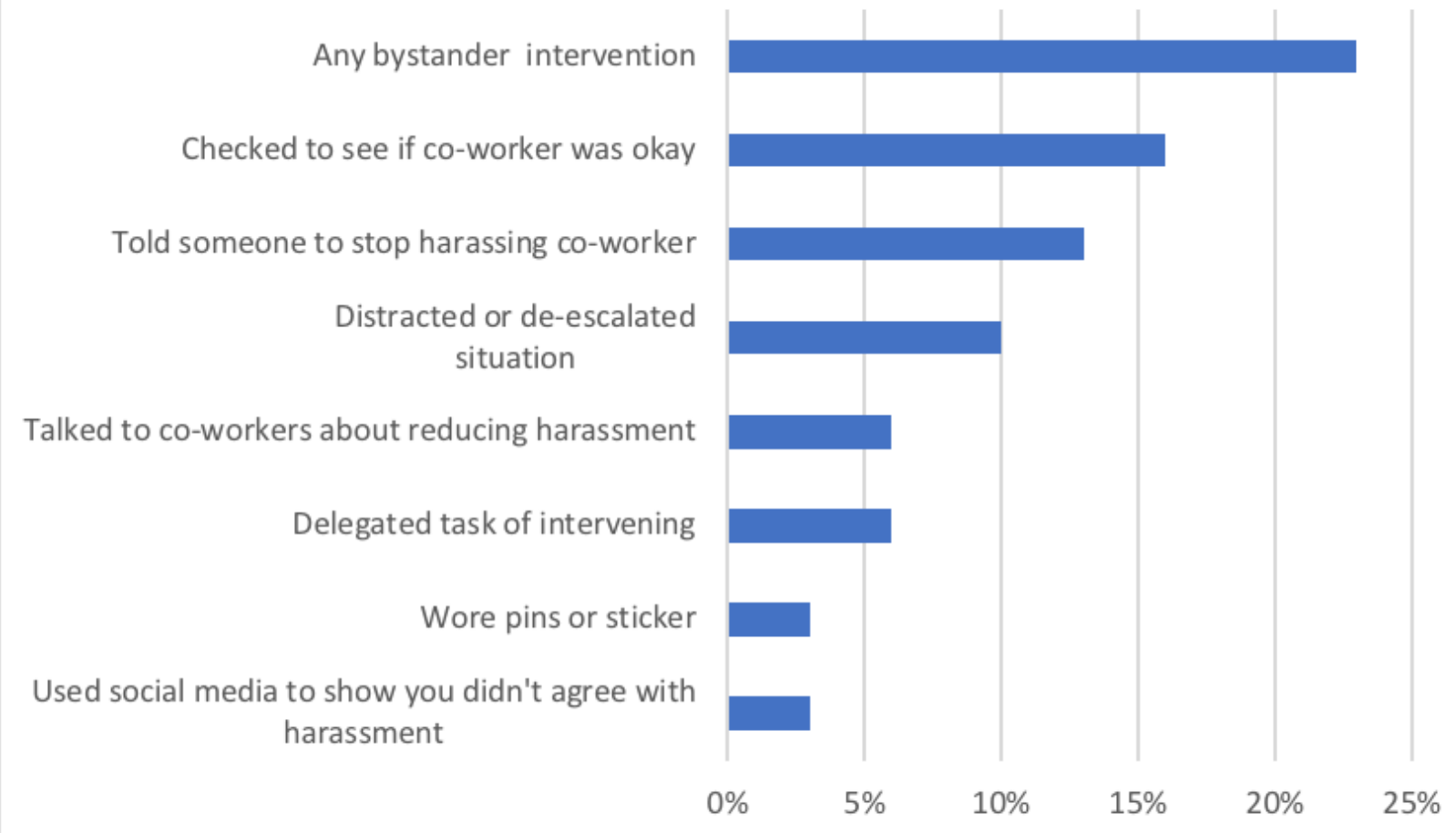

Figure 6.1. Percentage of Workers Reporting Bystander Intervention on the Job Site in the Last Month, by Type of Intervention

In responses to open ended questions, six (of 31) participants provided examples of how they had intervened when they had observed aggression on the job site:

An apprentice that worked for me got a degrading nick name and I pulled each crew member aside separately and in private and explained that was not going to be tolerated and why. 
I stood up for a group of workers being unfairly yelled at

I asked the person if they are ok and if I can help them.

A man said something about building our Mexican wall, he was joking, but I said that wasn't funny at all.

Many times. Changing the subject or deflecting from the person being talked down to

I do this all the time as part of my role as supervisor and as a compassionate human.

Women, people of color, supervisors were more likely to engage in a bystander intervention in the last month (Figure 7). Journey workers were much less likely than others to intervene. It is noteworthy that journey workers report experiencing and seeing harassment at similar (or higher) rates than other groups but are less likely to intervene and seem more fearful of intervening (specifically, fearful of losing their job).

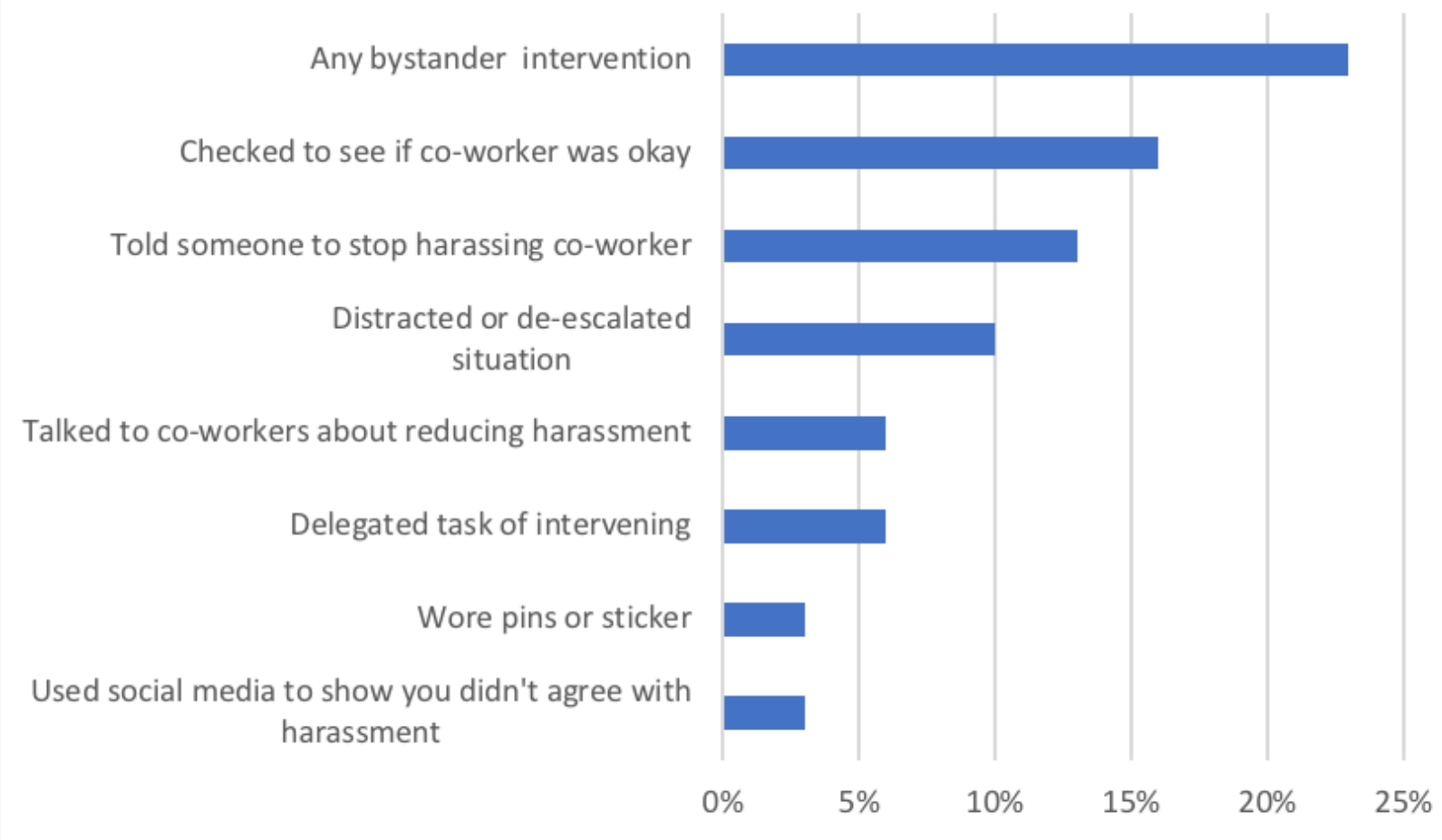

Figure 6.2. Percentage of Workers Reporting any Bystander Intervention, by Demographic Characteristics 


\subsection{NEXT STEPS}

Wave two surveys are scheduled to be administered in August 2018; wave three surveys are scheduled to be administered in February 2019. The pilot study will be evaluated as successful if reported levels of harassment go down and reported bystander interventions go up.

\subsection{REFERENCES}

Wilkinson, Lindsey and Maura Kelly. 2016. (Still) Building A More Diverse Workforce in the Highway Trades: 2016 Evaluation of the ODOT/BOLI Highway Construction Workforce Development Program. Final report submitted to the Oregon Bureau of Labor and Industries and Oregon Department of Transportation. Available at: http://www.pdx.edu/sociology/maura-kelly

Kelly, Maura and Sasha Bassett. 2015. Evaluation of the Potential for Adapting the Green Dot Bystander Intervention Program for the Construction Trades in Oregon. Final report submitted to the Oregon Bureau of Labor and Industries and Oregon Department of Transportation. Available at: http://www.pdx.edu/sociology/maura-kelly 



\subsection{APPENDICES}




\section{APPENDIX A}

\section{SAMPLE CHARACTERISTICS}

\begin{tabular}{|c|c|c|c|}
\hline Variable & Mean & Min & Max \\
\hline \multicolumn{4}{|l|}{ Gender } \\
\hline Men & $90 \%$ & & \\
\hline Women & $10 \%$ & & \\
\hline \multicolumn{4}{|l|}{ Race/Ethnicity } \\
\hline White & $77 \%$ & & \\
\hline Black & $6 \%$ & & \\
\hline Native American & $10 \%$ & & \\
\hline Latinx & $6 \%$ & & \\
\hline Other race & $6 \%$ & & \\
\hline Non-Hispanic White & $68 \%$ & & \\
\hline Racial/ethnic minority & $32 \%$ & & \\
\hline \multicolumn{4}{|l|}{ Position } \\
\hline Apprentice & $17 \%$ & & \\
\hline Journey Worker & $37 \%$ & & \\
\hline Supervisor & $40 \%$ & & \\
\hline \multicolumn{4}{|l|}{ Trade } \\
\hline Carpenter & $32 \%$ & & \\
\hline Electrician & $7 \%$ & & \\
\hline Laborer & $7 \%$ & & \\
\hline Operating Engineer & $4 \%$ & & \\
\hline Pile Driver & $4 \%$ & & \\
\hline Plumber & $14 \%$ & & \\
\hline Other & $32 \%$ & & \\
\hline Mean number of months on jobsite & 3 & 1 & 13 \\
\hline Mean age & 41 & 23 & 68 \\
\hline $\mathrm{N}$ & \multicolumn{3}{|c|}{31} \\
\hline
\end{tabular}




\section{APPENDIX B}

\section{PERCENTAGE REPORTING SELECTED ITEMS BY DEMOGRAPHIC CATEGORIES}

\begin{tabular}{|c|c|c|c|c|c|}
\hline & $\begin{array}{r}\text { Agree harassment } \\
\text { is a problem on } \\
\text { this jobsite }\end{array}$ & $\begin{array}{r}\text { Called names, } \\
\text { yelled at, cursed } \\
\text { at on jobsite }\end{array}$ & $\begin{array}{r}\text { I might not } \\
\text { intervene b/c } \\
\text { might make co- } \\
\text { worker angry }\end{array}$ & $\begin{array}{r}\text { I might not } \\
\text { intervene b/c } \\
\text { might get harassed }\end{array}$ & $\begin{array}{l}\text { Agree might not } \\
\text { intervene for fear } \\
\text { of losing job }\end{array}$ \\
\hline Full Sample & $13 \%$ & $26 \%$ & $12 \%$ & $10 \%$ & \\
\hline Men & $8 \%$ & $22 \%$ & $11 \%$ & $7 \%$ & \\
\hline Women & $67 \%$ & $67 \%$ & $0 \%$ & $33 \%$ & \\
\hline Non-Hispanic & & & & & \\
\hline White & $10 \%$ & $24 \%$ & $10 \%$ & $5 \%$ & \\
\hline $\begin{array}{l}\text { Racial-ethnic } \\
\text { minority }\end{array}$ & $20 \%$ & $30 \%$ & $20 \%$ & $20 \%$ & \\
\hline $\begin{array}{l}\text { Apprentice } \\
\text { Journey }\end{array}$ & $0 \%$ & $20 \%$ & $0 \%$ & $0 \%$ & \\
\hline Worker & $10 \%$ & $36 \%$ & $9 \%$ & $9 \%$ & \\
\hline Supervisor & $17 \%$ & $25 \%$ & $17 \%$ & $8 \%$ & \\
\hline $\mathrm{N}$ & & & 31 & & \\
\hline
\end{tabular}




\section{APPENDIX C \\ SURVEY QUESTIONNAIRE}

Thank you for your participation in the evaluation of the Green Dot program

Portland State University researchers are conducting an evaluation of the Green Dot program on construction job sites, which is designed to increase bystander behavior and reduce harassment, aggression, bullying, and hazing. The objective of the study is to learn more about people's experience with and observation of aggression on the job before and after the implementation of the Green Dot program. The study is sponsored by Oregon Tradeswomen, Inc., in collaboration with Portland State researchers and Green Dot Etc Inc. and in partnership with the Oregon Department of Transportation and the Bureau of Labor and Industries. If you choose to participate, you will be entered into a drawing for a $\$ 100$ Fred Meyer gift card.

You will be asked to complete a short survey, which will take about 10 minutes. Your participation is voluntary. You don't have to answer any questions you don't want to answer and you can stop at any time. Your answers to this survey will be kept completely confidential. Only the Portland State researchers conducting the project will have access to your survey. The information you provide will be kept confidential and your responses will not be shared with your employer. In reports from this study, your name and identifying information will not be included. The risks to participating in the study are minimal (e.g. thinking about negative past or future experiences working in the construction trades). Benefits of the study include contributing to research that will potentially improve the experiences of future workers in the construction trades. You will receive a copy of the above information, along with contact information for the Portland State Human Subjects Research Review Committee and the Portland State researcher conducting this project. By continuing the survey, you give your consent to participate in the study. 
1. The following are some statements about harassment, aggression, bullying, and hazing on your current jobsite. Please indicate how much you agree or disagree with the following statements

\begin{tabular}{|c|c|c|c|c|}
\hline How much do you agree or disagree? & $\begin{array}{l}\text { Strongly } \\
\text { Agree }\end{array}$ & Agree & Disagree & $\begin{array}{l}\text { Strongly } \\
\text { Disagree }\end{array}$ \\
\hline $\begin{array}{l}\text { I think workers are expected to formally report } \\
\text { harassment on this jobsite. }\end{array}$ & $\square$ & $\square$ & $\square$ & $\square$ \\
\hline $\begin{array}{l}\text { I think workers are expected to informally talk to a } \\
\text { supervisor (foreman/superintendent/project manager) } \\
\text { when we see harassment on this jobsite. }\end{array}$ & $\square$ & $\square$ & $\square$ & $\square$ \\
\hline $\begin{array}{l}\text { I think workers are expected to deal with harassment } \\
\text { on our own on this jobsite. }\end{array}$ & $\square$ & $\square$ & $\square$ & $\square$ \\
\hline $\begin{array}{l}\text { I think supervisors on this jobsite address harassment } \\
\text { when they see it or hear about it. }\end{array}$ & $\square$ & $\square$ & $\square$ & $\square$ \\
\hline $\begin{array}{l}\text { I think there are consequences for employees who } \\
\text { engage in harassment on this jobsite. }\end{array}$ & $\square$ & $\square$ & $\square$ & $\square$ \\
\hline $\begin{array}{l}\text { I might intervene and do something if I saw a co- } \\
\text { worker being harassed on this jobsite. }\end{array}$ & $\square$ & $\square$ & $\square$ & $\square$ \\
\hline $\begin{array}{l}\text { I might intervene if I saw a co-worker being harassed } \\
\text { on this jobsite because I think it is important for all } \\
\text { workers to play a role in keeping everyone safe. }\end{array}$ & $\square$ & $\square$ & $\square$ & $\square$ \\
\hline $\begin{array}{l}\text { I might intervene if I saw a co-worker being harassed } \\
\text { on this jobsite because I think of myself as someone } \\
\text { who helps others when I can. }\end{array}$ & $\square$ & $\square$ & $\square$ & $\square$ \\
\hline $\begin{array}{l}\text { I might not intervene if I saw a co-worker being } \\
\text { harassed on this jobsite because I would be concerned } \\
\text { I might make my co-workers angry. }\end{array}$ & $\square$ & $\square$ & $\square$ & $\square$ \\
\hline $\begin{array}{l}\text { I might not intervene if I saw a co-worker being } \\
\text { harassed on this jobsite because I would be concerned } \\
\text { I might start getting harassed. }\end{array}$ & $\square$ & $\square$ & $\square$ & $\square$ \\
\hline $\begin{array}{l}\text { I might not intervene if I saw a co-worker being } \\
\text { harassed on this jobsite because I would fear losing } \\
\text { my job. }\end{array}$ & $\square$ & $\square$ & $\square$ & $\square$ \\
\hline
\end{tabular}

\begin{tabular}{|c|c|c|c|c|}
\hline How much do you agree or disagree? & $\begin{array}{l}\text { Strongly } \\
\text { Agree }\end{array}$ & Agree & Disagree & $\begin{array}{l}\text { Strongly } \\
\text { Disagree }\end{array}$ \\
\hline I feel respected on this jobsite. & $\square$ & $\square$ & $\square$ & $\square$ \\
\hline I think harassment is a problem on this jobsite. & $\square$ & $\square$ & $\square$ & $\square$ \\
\hline $\begin{array}{l}\text { I have considered leaving this job site because of } \\
\text { harassment. }\end{array}$ & $\square$ & $\square$ & $\square$ & $\square$ \\
\hline $\begin{array}{l}\text { I think harassment on this job site negatively impacts } \\
\text { our safety. }\end{array}$ & $\square$ & $\square$ & $\square$ & $\square$ \\
\hline $\begin{array}{l}\text { I think harassment on this job site negatively impacts } \\
\text { our productivity. }\end{array}$ & $\square$ & $\square$ & $\square$ & $\square$ \\
\hline $\begin{array}{l}\text { I think more should be done to address harassment on } \\
\text { this jobsite. }\end{array}$ & $\square$ & $\square$ & $\square$ & $\square$ \\
\hline
\end{tabular}


2. Next are a few questions about experiences you may have had on this job site in the last month. Please indicate how often you have experienced the following on this job site.

\begin{tabular}{|c|c|c|c|c|c|}
\hline How many times in the last month have you... & $\begin{array}{c}0 \\
\text { times }\end{array}$ & $\begin{array}{c}1-2 \\
\text { times }\end{array}$ & $\begin{array}{c}3-5 \\
\text { times }\end{array}$ & $\begin{array}{c}6-9 \\
\text { times }\end{array}$ & $\begin{array}{c}10+ \\
\text { times }\end{array}$ \\
\hline Been called names, been yelled at, or been cursed at. & $\square$ & $\square$ & $\square$ & $\square$ & $\square$ \\
\hline Experienced unwanted sexual attention or comments. & $\square$ & $\square$ & $\square$ & $\square$ & $\square$ \\
\hline $\begin{array}{l}\text { Heard offensive jokes or comments directed towards } \\
\text { you. }\end{array}$ & $\square$ & $\square$ & $\square$ & $\square$ & $\square$ \\
\hline Been isolated or ignored at work. & $\square$ & $\square$ & $\square$ & $\square$ & $\square$ \\
\hline $\begin{array}{l}\text { Been unfairly denied opportunities to learn new } \\
\text { skills. }\end{array}$ & $\square$ & $\square$ & $\square$ & $\square$ & $\square$ \\
\hline $\begin{array}{l}\text { Been unfairly assigned to repetitive or low skill tasks } \\
\text { (like cleaning or flagging). }\end{array}$ & $\square$ & $\square$ & $\square$ & $\square$ & $\square$ \\
\hline $\begin{array}{l}\text { Been unfairly given fewer work hours than other } \\
\text { workers. }\end{array}$ & $\square$ & $\square$ & $\square$ & $\square$ & $\square$ \\
\hline $\begin{array}{l}\text { Experienced any harassment, aggression, bullying, or } \\
\text { hazing by workers on this job site. }\end{array}$ & $\square$ & $\square$ & $\square$ & $\square$ & $\square$ \\
\hline $\begin{array}{l}\text { Seen others be called names, be yelled at, or be } \\
\text { cursed at. }\end{array}$ & $\square$ & $\square$ & $\square$ & $\square$ & $\square$ \\
\hline $\begin{array}{l}\text { Seen others experience unwanted sexual attention or } \\
\text { comments. }\end{array}$ & $\square$ & $\square$ & $\square$ & $\square$ & $\square$ \\
\hline $\begin{array}{l}\text { Heard offensive jokes or comments directed towards } \\
\text { other workers. }\end{array}$ & $\square$ & $\square$ & $\square$ & $\square$ & $\square$ \\
\hline Seen others be isolated or ignored at work. & $\square$ & $\square$ & $\square$ & $\square$ & $\square$ \\
\hline $\begin{array}{l}\text { Seen others be unfairly denied opportunities to learn } \\
\text { new skills. }\end{array}$ & $\square$ & $\square$ & $\square$ & $\square$ & $\square$ \\
\hline $\begin{array}{l}\text { Seen others be unfairly assigned to repetitive or low } \\
\text { skill tasks (like cleaning or flagging). }\end{array}$ & $\square$ & $\square$ & $\square$ & $\square$ & $\square$ \\
\hline $\begin{array}{l}\text { Seen others unfairly assigned fewer work hours than } \\
\text { other workers. }\end{array}$ & $\square$ & $\square$ & $\square$ & $\square$ & $\square$ \\
\hline $\begin{array}{l}\text { Seen other workers experience any harassment, } \\
\text { aggression, bullying, or hazing by workers on this } \\
\text { job site. }\end{array}$ & $\square$ & $\square$ & $\square$ & $\square$ & $\square$ \\
\hline
\end{tabular}

3. Please briefly describe harassment you've seen on this job site: 
4. Next are some questions about things you may have done when you saw harassment, aggression, bullying, or hazing on this job site in the last month. Indicate how often you have done the following on this job site.

\begin{tabular}{|c|c|c|c|c|c|c|}
\hline $\begin{array}{l}\text { How many times in the last month have } \\
\text { you... }\end{array}$ & $\begin{array}{l}\text { I was } \\
\text { not in } \\
\text { this } \\
\text { situation }\end{array}$ & 0 times & $\begin{array}{c}1-2 \\
\text { times }\end{array}$ & $\begin{array}{c}3-5 \\
\text { times }\end{array}$ & $\begin{array}{l}\text { 6-9 } \\
\text { times }\end{array}$ & $\begin{array}{l}10 \text { or } \\
\text { more } \\
\text { times }\end{array}$ \\
\hline $\begin{array}{l}\text { Directly intervened by telling someone to } \\
\text { stop harassing a co-worker? }\end{array}$ & $\square$ & $\square$ & $\square$ & $\square$ & $\square$ & $\square$ \\
\hline $\begin{array}{l}\text { Directly intervened by checking with a co- } \\
\text { worker who has experienced harassment to } \\
\text { see if they are okay or need support? }\end{array}$ & $\square$ & $\square$ & $\square$ & $\square$ & $\square$ & $\square$ \\
\hline $\begin{array}{l}\text { Distracted or de-escalated a situation that } \\
\text { involves harassment (e.g., changed the } \\
\text { subject, asked for help with another task)? }\end{array}$ & $\square$ & $\square$ & $\square$ & $\square$ & $\square$ & $\square$ \\
\hline $\begin{array}{l}\text { Delegated the task of intervening in harassing } \\
\text { behavior to another coworker? }\end{array}$ & $\square$ & $\square$ & $\square$ & $\square$ & $\square$ & $\square$ \\
\hline $\begin{array}{l}\text { Talked to your co-workers about what you } \\
\text { could all do to reduce harassment on the } \\
\text { jobsite? }\end{array}$ & $\square$ & $\square$ & $\square$ & $\square$ & $\square$ & $\square$ \\
\hline $\begin{array}{l}\text { Used social media to show that you do not } \\
\text { agree with harassment on the jobsite? }\end{array}$ & $\square$ & $\square$ & $\square$ & $\square$ & $\square$ & $\square$ \\
\hline $\begin{array}{l}\text { Worn pins or stickers on your hardhat to } \\
\text { show you do not support harassment on the } \\
\text { jobsite? }\end{array}$ & $\square$ & $\square$ & $\square$ & $\square$ & $\square$ & $\square$ \\
\hline
\end{tabular}

5. Please briefly describe a time when you intervened and did something in response to harassment on this job site:

Finally, we would like to collect some demographic information

6. What is your position on this job site

$\square$ Apprentice

$\square$ Journey worker

$\square$ Other tradesperson

$\square$ Supervisor/foreman/superintendent/project manager

$\square$ Other (please specify):

7. What trade do you work in? (Please specify)

8. How many months have you been working on this job site? 
9. What is your gender?

$\square$ Male

$\square$ Female

$\square$ Non-binary

10. What is your race/ethnicity? (Please check all that apply)

$\square$ White

$\square$ Black or African American

$\square$ Asian or Asian American

$\square$ American Indian or Alaska Native

$\square$ Native Hawaiian or other Pacific Islander

$\square$ Latino/a, Hispanic, Spanish

$\square$ Another race/ethnicity, please specify:

11. What is your sexual orientation?

$\square$ Heterosexual or straight

$\square$ Sexual minority (e.g., gay, lesbian, bisexual, queer)

12. What is your age? 


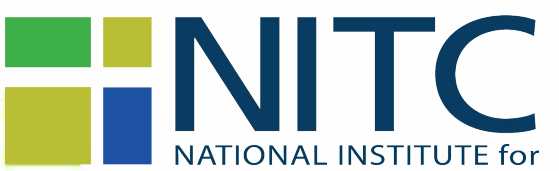

TRANSPORTATION and COMMUNITIES

Transportation Research and Education Center

Portland State University

1900 S.W. Fourth Ave., Suite 175

Portland, OR 97201 